\title{
Environmental Management Accounting, Islamic Social Reporting, and Corporate Governance Mechanism on Sharia-Approved Companies in Indonesia
}

\author{
Windu Mulyasari ${ }^{1,2} \&$ Sekar Mayangsari ${ }^{2}$ \\ ${ }^{1}$ University of Sultan Ageng Tirtayasa, Indonesia \\ ${ }^{2}$ Trisakti University, Jakarta, Indonesia \\ Correspondence: Windu Mulyasari, University of Sultan Ageng Tirtayasa, Indonesia.
}

Received: August 29, 2019

Accepted: October 17, 2019

Online Published: November 20, 2019

doi:10.5430/ijfr.v11n1p284

URL: https://doi.org/10.5430/ijfr.v11n1p284

\begin{abstract}
Issues of Islamic Social Reporting among Sharia-approved companies in Indonesia are still rare. Sharia-approved companies must comply with the sharia principles that have been approved by the Sharia Fatwa Council and the Financial Services Authority. The aim of this study is to obtain empirical evidence conformity of corporate environmental management accounting practices with the concept of Islamic Social Reporting. This study will also find evidence the effect of company's monitoring function to implementing Islamic Social Reporting.

The practice of corporate environmental management accounting is an interesting and important study because environmental issues are a complex issue. For Sharia-approved companies, the commitment to comply with sharia principles in environmental activities provides assurance to its specific investor that the business activities run according to sharia principles. The commitment to prevent sharia-based business activities is stronger when the company's monitoring function also strengthens the company's objectives in protecting the environment.

This study was conducted on Sharia-approved companies listed on the Indonesia Stock Exchange following the PROPER assessment from the Ministry of Environment. 38 companies were observed over a period of 3 years. The results of the study show that corporate governance has not provided a maximum monitoring function in the company. Companies are more obedient to the rules of law related to the environment. That is, for environmental protection companies are still in the concept of obeying the rules yet on awareness to integrate into the company's strategy.
\end{abstract}

Keywords: environmental management accounting, Islamic social reporting, Islamic corporate governance

\section{Introduction}

Corporate social responsibility is an important activity as corporate contribution to the community environment that aims to maintain the company's sustainability (Migdad, 2017; Moslemany and Etab, 2017). Corporate activities with the community environment are interdependent. The purpose of the company to maintain business sustainability is an activity to attract the public to receive products or services produced by the company so that the company gets a profit. The interdependence between companies and stakeholders is grown as a mutually beneficial relationship. If one feels aggrieved then the company can be threatened sustainability of its business. One of the important factors that are maintained by the company is environmental sustainability. Understanding to preserve the environment must be owned by each company in carrying out its activities. Corporate sustainability is closely related to the company's commitment to protect the environment.

This study aims to find evidence of environmental management accounting practices run by sharia-approved companies in the Indonesian Stock Exchange (IDX). Sharia-approved company securities have the criteria set by the Sharia Fatwa Council of the Majelis Ulama Indonesia and the Financial Services Authority. Companies must meet the criteria of adherence to sharia principles. For sharia-approved companies, means they must comply with the principles of sharia in running their business. In this research, the adherence to the principles of sharia in running its business is focused on the practice of environmental management accounting.

In the Islamic perspective, the preservation of the environment when carrying out human activities becomes an absolute necessity. The Word of Allah SWT in Al-A'rof 56 states: 
And do not you make mischief in the land, after (Allah) fix it and pray to Allah, with fear and hope. Truly grace and hope. Allah's mercy is very close to those who do well.

This verse prohibits doing damage on earth. The damage inflicted by humans on earth causes the greatness of God's grace and ultimately manifests itself. Guard against environmental sustainability because humans are created as caliphs on earth to guard it. The universe has been created by Allah SWT in a state that is very harmonious, and meets the needs of God's creatures. Humans are tasked with making use of and keeping for the good of all beings. Destructive after repair, much worse than damage it before it is repaired, or when it's bad. Therefore, this verse expressly underlines the prohibition.

The concept of that idea is implemented into the company as Corporate Social Responsibility (CSR). CSR is a form of corporate responsibility to preserve the environment because the company's business activities have utilized both natural and human resources. Sustainability of the company can be achieved as an implication of preserving the environment. Such responsibility is a form of corporate social contract.

Haniffa (2002) said that there is a need for Sharia-based corporate social performance reporting standards as a form of corporate social contract to the environment. Such reporting standards are required due to many limitations in conventional social reporting, so he proposes a conceptual framework of Islamic Social Reporting (ISR) which is based on Sharia provisions. ISR not only helps decision-making for specific investors (Muslims), it also helps companies in fulfilling their obligations to God and society.

Companies that meet the criteria of Sharia shares in their social reporting should consider corporate social reporting based on sharia principles. Companies as agents that run business activities must fulfill social responsibility to the environment. The fulfillment of the provisions of environmental management accounting practices with sharia principles make a real contribution by providing guarantees for stakeholders of corporate adherence to the principles of sharia.

The study also looked for evidence whether the monitoring function within the company is demonstrated by the application of corporate governance mechanisms. The monitoring function affects the compliance of environmental management accounting practices with the ISR. Studies on compliance with environmental management accounting practices and their relationship with ISR and ICG are limited. The expected benefit in this research is to broaden the insight of Social Responsibility study which has been applied by the company. This research is important because environmental protection is closely related to the rules contained in the Qur'an and Hadith. The compliance of the environmental management accounting practices conducted by the company to the Islamic Corporate Governance shows the level of corporate compliance with Sharia rules. This study refers from research from Ismail et al (2014) conducted in Malaysia. This study also investigates the influence of corporate governance in accordance with sharia (Islamic Corporate Governance) as a mechanism to monitor the practice of environmental management accounting according to sharia. Previous researches have been done more for the banking industry, while in this study developed for public companies that have the responsibility to carry out their business with the concept of sharia.

\section{Literature Review and Hypothesis Development}

In the Islamic view, life goes on the principle of harmony and balance. The existence of the universe has been created on the basis of harmonious arrangements and precise calculations, in a work system that is mutually supportive, interrelated, and interdependent with one another. So, if there is one problematic part that will surely cause another damage. This principle should be the guidance or ground of thinking for humans in living life on earth. Any action that is done must be based on the calculation and consideration in order to keep the principle of order and balance is reached.

Humans when running their activities must harmonize the harmony and balance of business and environment. That is, business activities undertaken humans together should remain aim and synergize to environmental sustainability. Ministry of Environment of the Republic of Indonesia in its Decision Letter no. 127 of 2002 on the Performance Rating Program of the Company in Environmental Management (PROPER) provides guidance and rating for companies that have run their business by aligning with their environment.

Sharia approved companies are a company that meets the criteria of sharia principles set by the Sharia Board. The criteria of sharia principles relate to business and financial activities. Business activities undertaken by a company should not contain gambling, gharar, fraud, haram and bribery. Sharia approved companies are enacted once every 6 months with the approval of the Sharia Fatwa Council which is the division of the Majelis Ulama Indonesia and the Financial Services Authority. In this research see the environmental management accounting practices of these companies in terms of Islamic Social Reporting (ISR). 


\subsection{The Practice of Environmental Management Accounting (EMA)}

Islamic teachings offer an opportunity to understand Sunnatullah and assert human responsibility. Islamic teachings not only teach to take advantage of natural resources, but also teach the rules of its use with attention to sustainable common welfare as the desired overall result. One of Sunnah Rasulullah SAW explains that every human being is entitled to benefit from natural resources owned together to meet the needs of his life as long as not infringe, violate or hinder the rights owned by others as human beings. Use of scarce or limited resources must be monitored and protected.

Environmental management accounting (EMA) practices are applied to overcome limitations in conventional management accounting that do not provide adequate information related to environmental management (Ranganathan and Ditz, 1996; Sulaiman and Mokhtar, 2010; Swamy, 2010). Ranganathan and Ditz (1996) state that hidden costs of environmental activities cannot be disclose using conventional management accounting. The disclosure of the hidden environmental costs of labor costs to maintain environmental related equipment that is not normally cost-effective (Kitzman, 2001) can provide more information for better decision-making (Ferreira et al., 2010; Gibson and Martin, 2004) and improve organizational performance (Sirisom and Sonthiprasat, 2011).

\subsection{Islamic Social Responsibility (ISR)}

Islamic Social Reporting (ISR) uses sharia principles as its basic foundation. Sharia principles in the ISR produce material, moral, and spiritual aspects that are the main focus of corporate social reporting. Islamic Social Reporting (ISR) is an extension of social reporting not only in the form of a great desire of the entire society to the role of the company in the economy but relating to the spiritual perspective (Haniffa, 2002). ISR emphasizes social justice in its reporting in addition to environmental reporting, minority interests and employees. These include issues related to the welfare of the people in trade activities such as income distribution (known as zakat). The important factor that shariah basis in the formation of Islamic Social Reporting (ISR) is Tawheed (One God) and not partnering with Him, giving all affairs to Allah and submitting to His commandments, believing that Allah belongs to the Kingdom of heaven and earth (Qur'an 57: 5), and then to Him you are returned (Qur'an 2:28). It directs the view of a Muslim to be willing to accept all the provisions that have been established by Islamic Sharia based on two main sources namely the Quran and Hadist. Sharia becomes the basis in every aspect of the life of a Muslim and is very influential in the prosperity of all human beings (society). In this dimension, Islamic Social Reporting (ISR) plays an important role especially for Muslim decision makers (Othman, Thani and Ghani, 2009). Disclosure reporting is a report of social responsibility on the basis of Islami with reference to the four principles that the purpose of ISR disclosure are: Profit (profit), People (community), Planet (environment) and Sharia.

The practice of environmental management accounting conducted by sharia approved companies, basically have to fulfill the concept in Islamic Social Responsibility. The company has a responsibility to the specific investor who has chosen special shares in this domain. Because there is a responsibility to the investor, the profit management accounting practices that he undertakes follow the compliance of the disclosure within the ISR.

Hypothesis 1: The practice of environmental management accounting in sharia approved companies is positively related to the disclosure of Islamic Social Responsibility.

\subsection{Corporate Governance ( $C G)$}

The standard of implementation of Islamic Corporate Governance refers to the standards set by AAOIFI which is one of the Islamic corporate governance systems for sharia financial institutions. Implementation of sharia corporate governance will be successful if it can meet some principles that have been regulated by PBI Number 11/33 / PBI / 2009 contains principles of good corporate governance management for sharia banks and sharia business that is transparency, accountability, responsibility, independence, and justice. The monitoring function in the ICG mechanism influences the environmental management accounting practices in order to comply with the ISR.

Hypothesis 2: Implementation of a high mechanism of Islamic Corporate Governance in sharia approved companies positively related to environmental management accounting practices in accordance with the disclosure of Islamic Social Responsibility

\section{Research Method}

\subsection{Sample and Data Collection}

This research is an empirical and structured research by looking for ISR index and ISR disclosure index as well as company environmental management accounting practice. This research is conducted on sharia approved companies that listing in Indonesia Stock Exchange at 2016-2018. 


\subsection{Measurement of Variables}

Environmental management accounting practice is measured based on the PROPER assessment from the Ministry of Environment. PROPER is a supervisory activity and incentive and/or disincentive program to the party responsible for the business and/or activity. PROPER based on performance appraisal of business activity of company especially related to environment. The activities are to: a). prevention of pollution and/or environmental damage; b). preservation of pollution and/or environmental damage; and c). recovery of pollution and/or environmental damage. A more complete PROPER Assessment Criteria can be viewed in the State Minister of Environment Regulation No. 5 of 2011 on the Corporate Performance Rating Program in Environmental Management. Measurements of environmental management accounting practices based on PROPER assessment are, 1) 5=Gold; 2) 4=Green; 3) 3=Blue; 4) 2=Red; 5) 1=Black.

The current Corporate Social Responsibility framework does not include spiritual concepts as a core aspect of explaining the involvement of organizations in social responsibility relating to their obligations to God. The current framework may not provide guidance for CSR practices by Islamic organizations. In conducting the disclosure of annual reports on sharia companies is measured by the score of the index of Islamic Social Reporting (ISR). The ISR index in this study was an index adopted from the Othman et al. (2009) study with several modifications according to the study. There are 43 items of disclosure categorized into six disclosure themes namely Finance and Investment, Products and Services, Employees, Social Activities, Environment and Corporate Governance. Each item has a value of 1 if expressed by the company, if not then the value of 0 . Measurement of the ISR index after the scoring follows the next formula as:

$$
\text { Disclosure level }=\frac{\text { number item filled }}{\text { maximum scor }}
$$

Islamic Corporate Governance as a monitoring function in this study is measured by a modified level of Corporate Governance disclosure. Modifications made by adding the Sharia Supervisory Board as a sharia control mechanism in the company. ISG size is as follows:

1) Proportion of Independent Board of Commissioners (BOARDSIZE).

2) Board of Directors (DIRECT).

3) Audit Committee (AUDIT).

The activity of environmental management accounting in this research is seen from the result of PROPER assessment from the Ministry of Environment. The PROPER assessment provides an overview of corporate responsibility and environmental management activities with defined standards. The results of the PROPER assessment are compared with the CSR corporate disclosure report. Corporate CSR disclosure is reviewed from indicators of Islamic Social Responsibility disclosure. Corporate Governance disclosure is measured by CG monitoring mechanism components and coupled with the components of the sharia supervisory board. Hypothesis 1 states that the practice of management accounting on companies listed in the Sharia effect is positively related to the disclosure of Islamic Social Responsibility. The equations for the hypothesis are:

$$
\text { ISR }=\alpha_{0}+\beta_{1} \text { PROPER }_{t}+\varepsilon
$$

ISR $=$ index of disclosure of Islamic Social Responsibility

PROPER = assessment of the company's environmental performance in year $\mathrm{t}$

Hypothesis 2 states that the implementation of a high mechanism of Islamic Corporate Governance in companies that adhere to Sharia principles is positively related to the practice of environmental management accounting in accordance with the disclosure of Islamic Social Responsibility. The equations for the hypothesis are:

$$
\begin{aligned}
\text { ISRD } & =\alpha_{0}+\beta_{1} \text { PROPER }+\beta_{2} \text { BOARDSIZE }+\beta_{3} \text { DIRECTBOARD }+\beta_{4} \text { AUDCOM } \\
& +\beta_{5} \text { COMBOARD } * \text { PROPER }+\beta_{6} \text { BOARDSIZE } * \text { PROPER }+\beta_{7} \text { DIRECTBOARD } * \text { PROPER } \\
& +\beta_{-} 8 \text { AUDCOM } * \text { PROPER }+\varepsilon
\end{aligned}
$$

ISR $=$ Index of Islamic Corporate Responsibility

PROPER $=$ Assessment of environmental performance in year $\mathrm{t}$

BOARDSIZE $=$ Proportion of independent commissioners

DIRECT $=$ Number of boards of directors 
AUDIT $=$ Number of audit committee members

\section{Result and Discussion}

Data analysis was conducted on 38 companies in 2016-2018 that meet the criteria in this study. The total number of samples in this study was 114 . The company is a company listed in the sharia securities and listed on the Indonesia Stock Exchange and obtained a PROPER rating from the Ministry of Environment. Sample companies according to type of industry in research can be seen in Table 1.

Table 1. Number of companies by industry

\begin{tabular}{lll}
\hline No & Industry & Number of samples \\
\hline 1 & Assorted Industries & 8 \\
\hline 2 & Consumer Goods Industry & 9 \\
\hline 3 & Basic Industries and Chemicals & 12 \\
\hline 4 & Infrastructure, Utilities and Transportation & 1 \\
\hline 5 & Trade, Services and Investment & 1 \\
\hline 6 & Mining & 4 \\
\hline 7 & Agriculture & 2 \\
\hline 8 & Property, Real Estate, and Building Construction & 1 \\
\hline & Total companies & 38 \\
\hline
\end{tabular}

The first stage of testing in this study is to describe the data into the sample. The results of statistical descriptive test can be seen in Table 2. Descriptive statistical results show that the ISR index has an average of 0.843 with a standard deviation of 0.057 . Sharia supervisory board has a value of 1 because all companies listed in the list of Islamic securities have received approval from the Sharia Supervisory Board of the Majelis Ulama Indonesia. So even though they do not have internal Sharia supervisory boards, but companies are listed on the Indonesia Stock Exchange once every 6 months to review whether they are obedient to the criteria of sharia. The proportion of the number of independent commissioners in the board of commissioners has an average of 0.369 with a standard deviation of 0.096. The composition of the board of directors has an average of 5.68 and a standard deviation of 2.248. The number of audit committees has an average of 3.04 with a standard deviation of 0.408 .

Tabel 2. Descriptive statistic

\begin{tabular}{llllll}
\hline & $\mathrm{N}$ & Minimum & Maximum & Mean & Std. Deviation \\
\hline Index ISR & 114 & 0,634 & 0,951 & 0,84360 & 0,055808 \\
\hline PROPER & 114 & 3 & 5 & 3.25 & 0,558 \\
\hline Board Size & 114 & 0 & 0,500 & 0,36904 & 0,096533 \\
\hline Boards of Directors & 114 & 2 & 11 & 5,68 & 2,248 \\
\hline Committe Audit & 114 & 2 & 5 & 3,04 & 0,408 \\
\hline Valid N (listwise) & 114 & & & & \\
\hline
\end{tabular}

\subsection{Hypothesis Testing}

Hypothesis 1 states that the practice of environmental management accounting in companies that adhere to sharia is positively related to the disclosure of Islamic Social Responsibility. The practice of environmental management accounting in this study is seen from the assessment of PROPER from the Ministry of Environment. The PROPER value shows the company's environmental management and safeguard practices. The result of regression test of hypothesis 1 can be seen in Table 3. 
Table 3. The influence of environmental management accounting to ISR disclosure test ISRD $=\alpha_{0}+\beta_{1}$ PROPER $_{\mathrm{t}}+\varepsilon$

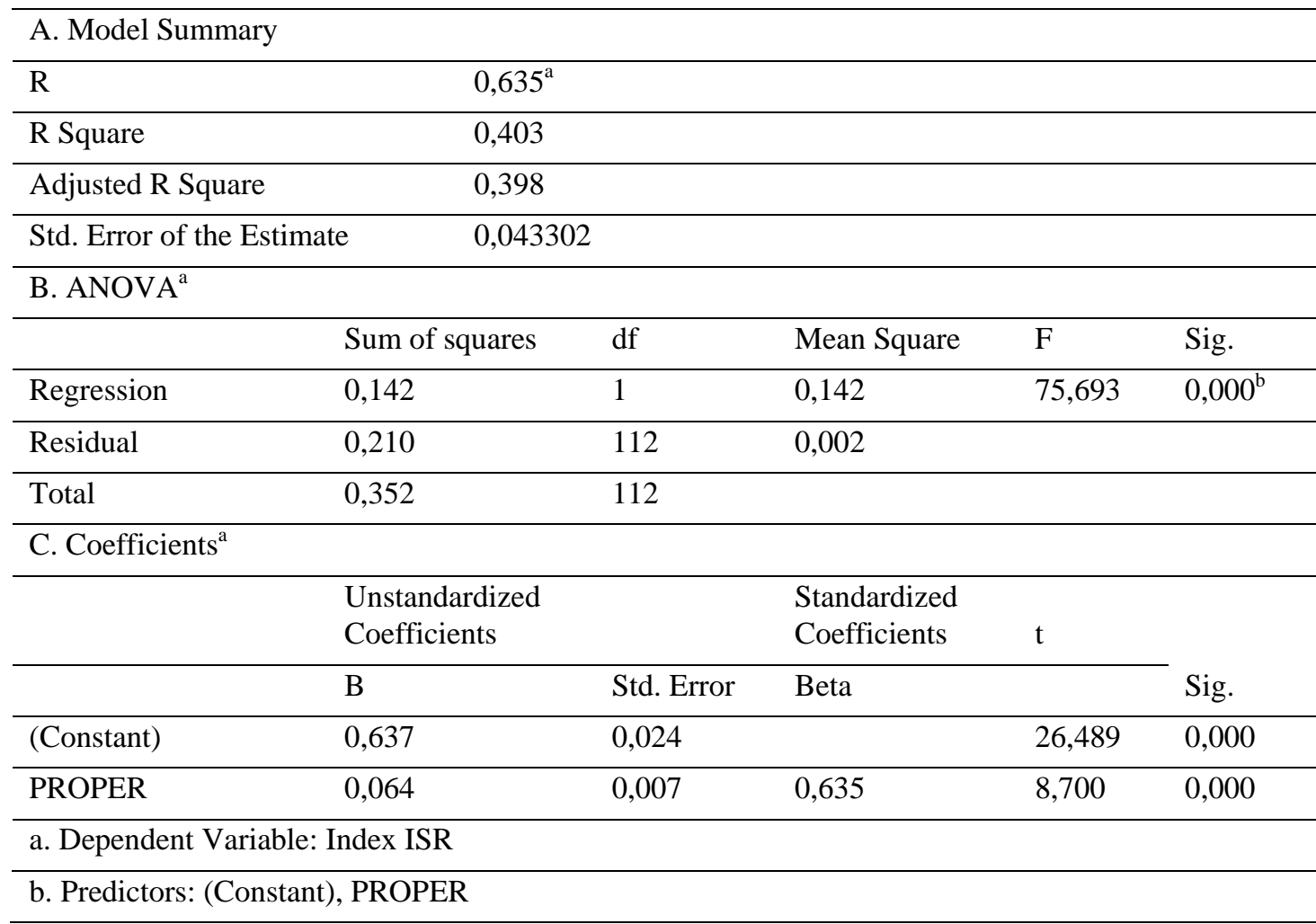

The result of hypothesis test shows that $R 2$ value 0,403 and F 75,693 (p-value 0,000) is statistically significant. So variable indpendent explain equal to $40,3 \%$ to variable dependent. PROPER coefficient value 0.064 ( $\mathrm{p}$-value = 0,000), so PROPER has a statistically significant effect on ISR disclosure.

Hypothesis 2 states that the implementation of a high mechanism of Islamic Corporate Governance in companies that adhere to Sharia principles is positively related to the practice of environmental management accounting in accordance with the disclosure of Islamic Social Responsibility. The results of the second hypothesis test can be seen in Table 4.

Table 4. Result of moderation effect test

IRD $=\alpha \_0+\beta \_1$ PROPER $+\beta \_2$ BOARDSIZE $+\beta \_3$ DIRECTBOARD $+\beta \_4$ AUDCOM $+\beta \_5$ COMBOARD $*$ PROPER $+\beta \_6$ BOARDSIZE $*$ PROPER $+\beta$ _7 DIRECTBOARD $*$ PROPER $+\beta \_8$ AUDCOM $*$ PROPER $+\varepsilon$

\begin{tabular}{|c|c|c|c|c|c|}
\hline \multicolumn{6}{|l|}{ A. Model Summary } \\
\hline $\mathrm{R}$ & $0,652^{\mathrm{a}}$ & & & & \\
\hline R Square & 0,425 & & & & \\
\hline Adjusted R Square & 0,387 & & & & \\
\hline Std. Error of the Estimate & 0,043679 & & & & \\
\hline \multicolumn{6}{|l|}{ B. ANOVA $^{\mathrm{a}}$} \\
\hline & Sum of squares & df & Mean Square & $\mathrm{F}$ & Sig. \\
\hline Regression & 0,150 & 7 & 0,021 & 11,210 & $0,000 \mathrm{~b}$ \\
\hline Residual & 0,202 & 106 & 0,02 & & \\
\hline Total & 0,352 & 113 & & & \\
\hline
\end{tabular}




\begin{tabular}{llllll}
\hline C. Coefficients $^{\mathrm{a}}$ & \multicolumn{3}{l}{} & \\
\hline & $\begin{array}{l}\text { Unstandardized } \\
\text { Coefficients }\end{array}$ & & $\begin{array}{l}\text { Standardized } \\
\text { Coefficients }\end{array}$ & $\mathrm{t}$ & \\
\hline & $\mathrm{B}$ & Std. Error & Beta & & Sig. \\
\hline (Constant) & 1,192 & 0,425 & & 2,804 & 0,006 \\
\hline PROPER & $-0,095$ & 0,135 & $-0,946$ & $-0,700$ & 0,486 \\
\hline BOARDSIZE & $-0,342$ & 0,342 & $-0,591$ & $-1,000$ & 0,320 \\
\hline DIRECT & $-0,002$ & 0,113 & $-0,017$ & $-0,022$ & 0,983 \\
\hline AUDIT & $-0,387$ & 0,279 & $-0,884$ & $-1,385$ & 0,169 \\
\hline BOARDSIZE*EMA & 0,091 & 0,107 & 0,646 & 0,859 & 0,392 \\
\hline DIRECT*EMA & $-0,002$ & 0,037 & $-0,062$ & $-0,048$ & 0,962 \\
\hline AUDIT*EMA & 0,116 & 0,087 & 1,596 & 1,326 & 0,188 \\
\hline
\end{tabular}

a. Dependent Variable: Index ISR

b. Predictors: (Constant), CAUDITEMA, Board Size, DIRECT, CAUDIT, BOARDSIZE*EMA, PROPER, DIRECTEMA

The result of hypothesis 2 test shows that there is no moderation influence of corporate governance mechanism on the relationship between environmental management accounting practice to Islamic Social Reporting. The test results give statistically insignificant results on all the variables tested. The full results can be seen in Table 4 . The test results show that the monitoring function within the company has no influence on the practice of environmental management accounting. This phenomenon can be caused by the practice of environmental management accounting here in terms of assessment by the Ministry of Environment. Thus, the likelihood of a company is more affected by compliance with government regulations to implement environmental management accounting practices in accordance with regulations. The PROPER assessment criteria refer to environmental safeguards and reservations. These criteria are in harmony with the principles of social responsibility according to sharia.

\section{Conclusion}

This study aims to look for evidence of environmental management accounting practices implemented by sharia approved companies. The company has a responsibility to report its business activities in accordance with sharia principles. The company's activities in conducting its business to protect the environment include one of the consequences that must be executed by the company to maintain the company's sustainability. In this study the practice of environmental management accounting is viewed from the conformity with the ISR. The suitability of the implementation of environmental responsibility is also influenced by the company's commitment to implement it by looking at the governance being implemented. Furthermore, this research sees the influence of ICG as a monitoring mechanism of the company in implementing company policy.

This study provides evidence that environmental management accounting practices based on PROPER assessment have an effect on Islamic Social Reporting. However, testing the moderation effects on these relationships yielded no statistically significant results. Internal monitoring function within the company does not exert a strong influence on the practice of environmental management accounting. The strong influence on environmental responsibility is due to the company's adherence to government regulation in this case the environmental performance standards set by the Ministry of Environment. The results can provide input to the regulatory body, that companies are more obedient to government regulation. Thus safeguards and reservations on the environment can be imposed by the government through regulations that must be run by the company.

The study also aims to see the disclosure of Islamic Social Reporting on companies listed in the list of Islamic securities. Companies included in the list of sharia securities have criteria established and approved by the Sharia Fatwa Council and the Financial Services Authority. However, in practice, the disclosure related to business compliance with Sharia principles has not existed in these companies. This condition can be a concern for regulators to establish disclosures that should be done by companies listed in the sharia securities so that investors obtain information related to the company's business adherence to the principles of sharia. 
This study still has a weakness that is the assessment of environmental management accounting practices using external assessments of the Ministry of Environment. This may cause bias because the company's compliance with environmental management accounting practices is based on compliance to the government. For further research should develop measurement indicators of environmental management accounting practices, especially those based on sharia principles for companies that adhere to the principles of sharia. Another disadvantage of this research is that the company being the sample is a company that is listed in the sharia securities and listed on the Indonesia Stock Exchange. These companies are basically companies whose articles of association do not specify that the company is doing sharia business. Subsequent research needs to develop appropriate indicators for these companies. Because the listed companies have shares whose business activities are adhered to the principles of sharia.

\section{References}

Barriers, W. S. (2010). To The Development of Environmental Management Accounting: An Exploratory Study of Plup and Paper Companies In Thailand. EuroMed Journal of Business, 5(3), 315-331. https://doi.org/10.1108/14502191011080836

Bhattacharya, C. B., Korschun, D., \& Sen, S. (2008). Strengthening stakeholder-company relationships through mutually beneficial corporate social responsibility initiatives. Journal of Business Ethics, 85, 257-272. https://doi.org/10.1007/s10551-008-9730-3

Darus, F., Yusoff, H., \& Mohd Azhari, N. K. (2013). Environmental disclosure of Islamic financial institutions (IFIs): Preliminary evidence from Malaysia. Journal of Energy Technologies and Policy, 3(11), 433-439.

Ferreira, A., Moulang, C., \& Hendro, B. (2010). Environmental management accounting and innovation: an exploratory analysis. Accounting, Auditing and Accountability Journal, 23(7), 920-948. https://doi.org/10.1108/09513571011080180

Gibson, K. C., \& Martin, B. A. (2004). Demonstrating value through the use of environmental management accounting. Environmental Quality Management, 13(3), 45-52. https://doi.org/10.1002/tqem.20003

Haniffa, R. (2002). Social Reporting Disclosure: An Islamic Perspective. Indonesian Management \& Accounting Research, 1(2), 128-146.

Ismail, M. S., Ramli, A., \& dan Darus, F. (2014). Environmental Management Accounting Practices And Islamic Corporate Social Responsibility Compliance: Evidence from ISO14001 companies. Social and Behavioral Sciences, 145, 343-351. https://doi.org/10.1016/j.sbspro.2014.06.043

Ismail, M. S., Ramli, A., \& Darus, F. (2014). Environmental Management Accounting Practices and Islamic Corporate Social Responsibility Compliance: Evidence From ISO14001 Companies. Procedia-Social and Behavioral Sciences, 145, 343-351. https://doi.org/10.1016/j.sbspro.2014.06.043

Jusoh, W. N. H. W., Ibrahim, U., \& Napiah, M. D. M. (2015). An Islamic Perspective on Corporate Social Responsibility of Islamic Banks. Mediterranean Journal of Social Science, 6(2), 308-315. https://doi.org/10.5901/mjss.2015.v6n2s1p308

Kementerian Lingkungan Hidup. (2016). Retrieved from http://proper.menlh.go.id/portal/

Kitzman, K. A. (2001). Environmental Cost Accounting for Improved Environmental Decision Making. Pollution Engineering, 33(11), 20-23.

Meutia, I., \& Febrianti, D. (2017). Islamic Social Reporting In Islamic Banking: Stakeholders Theory. In SHS Web of Conferences (Vol. 12001, pp. 2-8). https://doi.org/10.1051/shsconf/20173412001

Mhemed Ahmad Issalih, F., Amran, A., Darus, F., Yusoff, H., \& Zain, M. M. (2015, Jan-March). Islamic Corporate Social Reporting : Perspective of Makasid Al Shariah. Journal of Islamic Economics, Banking and Finance, 11(1). https://doi.org/10.12816/0026020

Migdad, A. M. (2017). CSR practices of Palestinian Islamic banks: contribution to socio-economic development. ISRA International Journal of Islamic Finance, 9(2), 133-147. https://doi.org/10.1108/IJIF-06-2017-0001

Moslemany, R. E., \& Etab, M. (2017, March). The effect of corporate social responsibility disclosures on financial performance in the banking industry: empirical study on Egyptian banking sector. International Journal of Business and Economic Development, 5(1).

Othman, R., Thani, A. M., \& Ghani, E. K. (2009). Determinants of Islamic Social Reporting Among Top Shariah-Approved Companies in Bursa Malaysia. Research Journal of International Studies, (12), 4-20. 
Putra, M. P., Takidah, E., \& ARafat, M. Y. (2014). Determinant on Islamic Social Reporting in Islamic Banking (Case Study in Indonesia). In International Conference of Global Islamic Studies (pp. 89-102).

Ramli, A. (2010). Value Engineering development in Malaysia: a diffusion study. Unpublished Ph.D, Universiti Teknology MARA, Shah Alam

Ranganathan, J., \& Ditz, D. (1996). Environmental Accounting: A Tool for Better Management. Management Accounting, 38-40.

Sirisom, J., \& Sonthiprasat, R. (2011). Environmental Management Accounting Effect On EMS And Firm Performance. Review of Business, 11(4), 127-134.

Sujana, A. (2015, August 19). The Extent of Corporate Social Responsibility Engagement in Malaysian Banks Offering Islamic Banking Services. Journal of Internet Banking and Commerce.

Sulaiman, M., \& Mokhtar, N. (2010). Environmental Management Accounting: Some emperical evidence from Malaysia. Malaysian Institute of Accountants, 11-51.

Swamy, K. (2010). Financial Management Call for Need-Based Structured Environment Accounting Standards. Journal of Financial Managment and Analysis, 23, 111-115.

Yusoff, H., Darus, F., Fauzi, H., \& dan Purwanto, Y. (2013). Exploring the Environmental Reporting Practices of Islamic Banks: A Case of Malaysia and Indonesia. Journal of Energy Technologies and Policy, 3(11). 